Jurnal Penelitian Perawat Profesional

Volume 3 Nomor 1, Februari 2021

e-ISSN 2715-6885; p-ISSN 2714-9757

http://jurnal.globalhealthsciencegroup.com/index.php/JPPP

\title{
ETLINGERA ELATIOR SEBAGAI ANTIHPERGLIKEMI PADA PENDERITA DIABETES MELLITUS
}

\author{
Hanifah Sapto Putri \\ Fakultas Kedoktern, Universitas Lampung, Jl. Prof. DR. Ir. Sumatri Brojonegoro No.1, Gedong Meneng, \\ Kec. Rajabasa, Kota Bandar Lampung, Lampung, Indonesia 35145 \\ hanifahsp18@gmail.com (+6287794441985)
}

\begin{abstract}
ABSTRAK
Etlingera elatior atau kecombrang merupakan salah satu tanaman yang memiliki berbagai efek farmakologis diantaranya yaitu sebagai antihiperglikemi pada penyakit diabetes mellitus. Tujuan literature review ini yaitu untuk mengetahui efek tanaman kecombrang dalam menurunkan kadar gula darah pada penderita diabetes melitus. Sumber yang digunakan terdiri dari dua puluh delapan sumber yang berasal dari Google Scholar, Pubmed, NCBI, Elsevier, dan situs-situs lainnya dengan rentang waktu 2010-2020. Artikel tersebut kemudian dianalisis dengan metode systematic literature review yaitu mengumpulkan, mengevaluasi dan mengembangkan penelitian pada fokus topik tertentu. Dari beberapa penelitian yang dilakukan didapatkan hasil bahwa tanaman kecombrang memiliki manfaat sebagai antihiperglikemi. Di mana senyawa aktif seperti flavonoid, fenolik dan saponin yang ada pada tanaman kecombrang memiliki kemampuan menghambat enzim amilase dan glukosidase, menetralkan radikal bebas, serta sebagai proteksi terhadap kerusakan sel beta pankreas dalam aktivitas antihiperglikemi pada pasien diabetes melitus.
\end{abstract}

Kata kunci: antihiperglikemi; diabetes mellitus; etlingera elatior

\section{ETLINGERA ELATIOR AS AN ANTIHYPERGLYCEMIC IN DIABETES MELLITUS}

\begin{abstract}
Etlingera elatior or kecombrang is a plant that has various pharmacological effects, including as an antihyperglycemic in diabetes mellitus. The purpose of this literature review is to determine the effect of kecombrang plants in reducing blood sugar levels in people with diabetes mellitus. The sources used consisted of twenty-eight sources from Google Scholar, Pubmed, NCBI, Elsevier, and other sites from 2010-2020. The article is then analyzed using a systematic literature review method, namely collecting, evaluating and developing research on a particular focus topic. From several studies conducted, it was found that the kecombrang plant has benefits as an antihyperglycemic. Where active compounds such as flavonoids, phenolics and saponins present in kecombrang plants have the ability to inhibit amylase and glucosidase enzymes, neutralize free radicals, and protect against damage to pancreatic beta cells in antihyperglycemic activity in diabetes mellitus patients.
\end{abstract}

Keywords: antihyperglicemic; diabetes mellitus; etlingera elatior 


\section{PENDAHULUAN}

Diabetes Mellitus (DM) atau penyakit kencing manis merupakan gangguan metabolik dimana ditandai dengan adanya peningkatan kadar glukosa darah (WHO, 2019). Gejala klinis yang khas yaitu adanya peningkatan kadar glukosa darah (hiperglikemi) yang disebabkan oleh berbagai faktor, di antaranya karena resistensi insulin maupun kegagalan sel beta pankreas dalam mempertahankan insulin yang keluar sesuai kebutuhan sebagai kompensasi penurunan insulin (Kahn, Cooper, \& Del Prato, 2014). Diabetes Mellitus terbagi menjadi dua tipe, yaitu diabetes mellitus tipe 1 (DM tipe 1) dan diabetes mellitus tipe 2 (DM tipe 2). Diabetes tipe 1 disebabkan akibat rusaknya sel beta pankreas (sering autoimun) sehingga terjadi defisiensi insulin, paling sering menyerang anakanak dan dewasa muda, sedangkan DM tipe 2 umumnya karena insulin yang resisten sehingga menyebabkan hiperglikemi. Diabetes mellitus memiliki kriteria diagnostik tersendiri yaitu jika kadar glukosa plasma sewaktu $\geq 200$ $\mathrm{mg} / \mathrm{dL}(\geq 11,1 \mathrm{mmol} / \mathrm{L})$, glukosa plasma puasa $(8-12$ jam $) \geq 126 \mathrm{mg} / \mathrm{dL} \quad(7,0$ $\mathrm{mmol} / \mathrm{L})$ dan nilai OGTT 2 jam $\geq 200 \mathrm{mg} / \mathrm{dL} \quad(\geq 11,1 \quad \mathrm{mmol} / \mathrm{L})$ (Petersmann et al., 2019). Komplikasi yang mungkin terjadi akibat diabetes tidak terkontrol akan menyebabkan penyakit seperti nefropati, neuropati ataupun retinopati diabetik (Handayani et al., 2019).

Prevalensi penderita DM tipe 2 mencapai lebih dari 400 juta penduduk di seluruh dunia (Zimmet, 2016). Obesitas dan overweight menyumbang faktor resiko terjadinya DM tipe 2 (WHO, 2019). Genetik, gaya hidup serta faktor lingkungan juga berperan dalam meningkatkan prevalensi DM tipe 2 (Willer, Harreiter, \& Pacini, 2016). Diabetes mellitus tipe 2 terjadi karena adanya induksi resistensi insulin dari otot rangka, hepar dan jaringan adiposa. Otot rangka sebagai organ utama yang memiliki tanggungjawab sebagai pemecahan glukosa pada pasien diabetes mellitus. Namun, jika resistensi insulin terjadi pada otot rangka akan mengurangi kapasitas pemecahan glukosa. Hiperglikemi disebabkan karena terjadinya stres oksidatif di dalam tubuh sehingga mengakibatkan penurunan aktivitas insulin ataupun sekresi insulin (Nor et al., 2020). Pada tingkat sel, resistensi insulin di otot terjadi karena gangguan penerimaan transporter GLUT4 yang membawa glukosa ke membran plasma, berkurangnya kapasitas penyimpanan glikogen, reduksi oksidasi glukosa, dan adanya gangguan pada mitokondria (Javeed \& Matveyenko, 2018). Menurut Li et al. (2016), kadar asam lemak bebas serta hiperglikemi pada penderita diabetes mellitus akan meningkatkan regulasi microRNA lewat mekanisme stress oksidatif sehingga menyebabkan disfungsi endotel. Stres oksidatif terjadi karena tidak seimbangnya produksi radikal bebas dengan perlindungan antioksidan yang ada di tubuh.

Selain meningkatnya pasien diabetes dari tahun ke tahun, pengobatan antidiabetes sintetik yang tersedia dapat dikatakan cukup mahal, dan juga pengobatan diabetes mellitus butuh terapi jangka panjang. Kondisi inilah yang akan memberatkan ekonomi pasien. Dari masalah tersebut, banyak masyarakat yang mengalihkan perhatiaannya selain pengobatan medis juga menambah dengan terapi non medis (herbal) sebagai terapi pendamping obat antidiabetes. Beberapa tahun belakangan ini sudah mulai banyak perkembangan obat-obatan yang terbuat dari bahan alami berupa tanaman herbal. Tanaman yang dipakai adalah yang memiliki kadar 
antioksidan yang tinggi guna mencegah stres oksidatif dengan cara menstabilkan radikal bebas (Patel et al., 2013).

Kecombrang (Etlingera elatior) merupakan tanaman yang mudah ditemui dan tersebar luas di Indonesia. Tanaman ini mudah tumbuh dan tidak perlu perhatian khusus dalam merawat serta mengolahnya. Tanaman yang termasuk ke dalam keluarga Zingiberaceae banyak dibudidayakan dan digunakan di negara asia tenggara, seperti Indonesia, Malaysia dan Thailand. Di Indonesia dan Malaysia, bagian kecombrang yang sering digunakan yaitu bagian bunga, kecombrang muda, ataupun bagian rimpangnya. Kecombrang ini dapat digunakan sebagai makanan, pengobatan, campuran air mandi ataupun memasak ikan. Di Thailand, kecombrang muda digunakan sebagai obat tradisional karena memiliki efek antifungi (Handayani et al., 2019). Selain efek antifungi, E. elatior juga memiliki efek farmakologis lain seperti antimikroba, antioksidan, antikanker, antidiabetes, antiinflamasi dan anti aging (Nor et al., 2020).

Beberapa peniliti menyatakan bahwa di dalam Etlingera elatior mengandung senyawa fitokimia seperti fenol, flavonoid, glikosida, saponin, tanin, steroid, alkaloid, dan terpenoid. Kandungan senyawa fenol dan flavonoid banyak ditemukan dalam jumlah yang cukup tinggi pada bagian daun, batang, dan rimpang (Chan et al., 2011). Peneliti lain mengungkapkan bahwa pada ekstrak bunga E. elatior dapat menghambat potensi aktivitas antioksidan dengan cara menigkatkan kadar enzim antioksidan itu sendiri, seperti superoksida dismutase, glutathion peroksidase, antioksidan total dan peroksidase lipid yang rendah serta kadar protein karbonil (Jackie et al.,
2011). Berdasarkan hasi penelitian lain menyatakan bahwa aktivitas antioksidan dan antikanker yang kuat pada E. elatior dapat memungkinkan tanaman ini sebagai senyawa terapeutik (Ghasemzadeh et al., 2015). Meskipun berbagai aktivitas farmakologis $E$. elatior sudah banyak diketahui, namun artikel ini memiliki tujuan untuk mengetahui pengaruh tanaman obat Etlingera elatior dalam menurunkan kadar glukosa darah pada pasien diabetes mellitus. Jenis penelitian ini berbeda dengan penelitian lain karena artikel ini menggunakan metode literature review yang bertujuan untuk mengetahui pengaruh tanaman kecombrang dalam menurunkan kadar gula darah pada penderita diabetes mellitus.

\section{METODE}

Penelitian ini menggunakan studi literature review, dengan langkah analitis mencari dan menggabungkan beberapa intisari serta menganalisis fakta dari berbagai sumber ilmiah yang cocok dengan kriteria yang valid dan akurat. Tinjauan literatur menyajikan ringkasan berupa publikasi paling relevan, kemudian membandingkan hasil yang disajikan dalam makalah. Sumber data yang digunakan dalam artikel ini terdiri dari sumber data primer dan tersier. Sumber data primer dalam artikel ini berupa jurnal ilmiah, baik nasional maupun internasional. Sedangkan untuk sumber tersier berupa situs - situs web terpercaya seperti Google Scholar, Pubmed, NCBI, Elsevier, dan situs-situs lainnya. Kriteria inklusi yang digunakan pada jurnal ini yaitu jurnal-jurnal saintifik nasional maupun internasional (2010-2020). Kata kunci yang digunakan yaitu Etlingera elatior, antihiperglikemi dan diabetes melitus sehingga didapatkan hasil berupa dua puluh delapan artikel yang dianggap relevan dari lima puluh artikel yang didapat pada 
studi ini. Analisis dilakukan dengan menggunakan metode systematic literature review yang ditelaah, diidentifikasi, dikaji dan dievaluasi hasil dan pembahasannya sehingga dapat dikembangkan penelitian pada fokus tertentu.

\section{HASIL}

Etlingera elatior memiliki kadar antioksidan yang tinggi sehingga dapat mencegah atau menghambat pembentukan radikal bebas (Maimulyanti \& Prihadi, 2015). Dari penelitian yang dilakukan Chan et al. (2011) menjelaskan bahwa komponen yang terkandung dalam tanaman E. elatior memiliki potensi untuk dikembangkan menjadi tanaman fungsional. Pada rizoma, komponen kimianya yaitu diarylheptanoids, labdane diterpenoids, dan steroid. Di bagian bunganya menunjukkan adanya senyawa flavonoid, terpenoid, saponin, tannin, dan karbohidrat. Dari daunnya, ditemukan flavonoid dan asam caffeoylquinic. Beberapa esensial oil sedikitnya ada 99 jenis di daun, 62 jenis di rhizoma, 26 jenis di batang dan 95 jenis di bunga. Beberapa jenis esensial oil yaitu linalool, menthol, limonene dan polypenol dari golongan fenolik terbukti memiliki aktivitas antioksidan. (Silalahi, 2016). Bagian dari Etlingera elatior yang digunakan sebagai antioksidan terdapat pada bagian daun, rhizoma, bunga dan bijinya. Dari beberapa penelitian menyatakan bahwa dibandingkan dengan rhizoma, daun $E$. elatior memiliki kemampuan antioksidan delapan kali lebih tinggi (Chan et al., 2011). Hal ini berhubungan dengan senyawa fenolik yang terkandung pada bagian tersebut (Ghasemzadeh et al., 2015).

Berdasarkan penelitian yang dilakukan Syarif et al. (2015) didapatkan bahwa pada ekstrak metanol rimpang kecombrang, selain memiliki saponin dan flavonoid, ekstrak rimpang methanol juga memiliki senyawa fenolik rata-rata sebesar $0,14443 \mathrm{ug} / \mathrm{ml}$ yang diukur menggunakan KLT-Densitometri. Senyawa fenolik ini berfungsi sebagai antimikroba dan antioksidan (Andarwulan et al., 2010). Hasil penelitian lain mengemukakan bahwa ekstrak etil asetat bunga E. elatior memiliki antioksidan dengan nilai $\mathrm{IC}_{50}$ sebesar 68,24 ug/ml sedangkan ekstrak metanol kadar nilai antioksidan lebih tinggi dengan nilai kadar $\mathrm{IC}_{50}$ sebesar $21,14 \mathrm{ug} / \mathrm{ml}$. Hal ini menunjukkan bahwa semakin kecil nilai $\mathrm{IC}_{50}$ menunjukkan semakin tinggi aktivitas antioksidannya (Maimulyanti \& Prihadi, 2015). Pada penelitian yang dilakukan oleh Fitrianita et al. (2018) diketahui bahwa pada daun kecombrang terkandung senyawa fitokimia berupa antrakuinon, saponin, fenol, flavonoid, dan steroid atau triterpenoid. Handayani (2014) juga melaporkan hal yang sama, namun berdasarkan penelitiannya terdapat senyawa tambahan yaitu alkaloid. Hal ini kemungkinan terjadi akibat tofografi, ketinggian, dan jenis organ yang digunakannya. Pada bagian lain, biji E. elatior terdeteksi mengandung senyawa terpenoid, flavonoid dan tanin (Rusanti, et al., 2017).

Pada penelitian Fitrianita et al. (2018), menyatakan bahwa ekstrak etanol $70 \%$ daun kecombrang dengan dosis 100 $\mathrm{mg} / \mathrm{kg}$ BB dapat menurunkan kadar glukosa darah hewan uji coba yang diinduksi aloksan dengan penurunan glukosa darah sebesar 76,62\% dibandingkan penggunaan obat glibenkamid $5 \mathrm{mg} / \mathrm{kgBB}$. Hasil dari penelitian lain mengatakan bahwa ekstrak ethanol tanaman E. elatior sebanyak $25 \mathrm{ug} / \mathrm{ml}$ menunjukkan 
inhibitor kuat pada enzim glukosidase dan amilase dibandingkan penghambatan obat acarbose (Juwita et al., 2018).

\section{PEMBAHASAN}

Senyawa kimia yang terdapat pada ekstrak kecombrang (Etlingera elatior) memiliki beberapa manfaat diantaranya yaitu sebagai antidiabetik (Nor et al., 2020). Ekstrak etanol $70 \%$ terbuat dari daun kecombrang yang disortasi basah, kemudian dicuci, lalu dikeringkan dan disortasi kembali. Setelah didisortasi, daun kecombrang dihaluskan hingga didapatkan serbuk simplisia daun kecombrang. Kemudian serbuk tersebut dimaserasi dengan etanol $70 \%$ hingga warna maserat menjadi jernih. Maserat kemudian difiltrasi dan filtratrnya dipekatkan hingga memperoleh ekstrak yang kental. Pada penelitian tersebut dikatakan bahwa dosis efektif yang digunakan yaitu $100 \mathrm{mg} / \mathrm{kgBB}$ sudah mampu menurunkan kadar glukosa darah pada hewan uji coba. Mekanisme ekstrak etanol $70 \%$ daun kecombrang dapat menurunkan hiperglikemi diduga adanya keterkaitannya dengan senyawa utama yang ada di dalamnya(Fitrianita $e t$ al., 2018). Penelitian lain menyatakan dosis $25 \mathrm{ug} / \mathrm{ml}$ sudah dapat menurunkan kadar gula darah. Mekanisme Ekstrak $E$. elatior $25 \mathrm{ug} / \mathrm{ml}$ yang dapat dijadikan sebagai antihiperglikemi yaitu dengan menghambat enzim glukosidase atau amilase. Selanjutnya penyerapan karbohidrat akan tertunda dan penyerapan gula setelah makan ikut tertunda. Akhirnya pengambilan glukosa dan glukosa darah berkurang (Juwita et al., 2018).

Kandungan senyawa metabolit sekunder seperti asam klorogenat dan flavonoid quersetin terlibat dalam metabolisme glukosa dengan memperbaiki mekanisme seluler pada uptake glukosa ke dalam sel, menghentikan kerja enzim alfa glukosidase, meningkatkan konsentrasi GIP (glucose dependent insulinotropic peptide), mengaktifkan AMPK. Hal ini mengakibatkan ekspresi dan translokasi GLUT-4 dapat meningkatkan uptake glukosa di jaringan perifer dan juga dapat menghambat aktivitas glukosa 6-fosfatase hepatik sehingga glukogenesis di hati menurun (Fitrianita et al., 2018).

Pada kondisi hiperglikemi, radikal bebas akan membentuk spesi oksigen reaktif yang melebihi kapasitas antioksidan sehingga terjadi stres oksidatif. Stres oksidatif dapat mengganggu proses apoptosis sel dan mengakibatkan tidak berfungsinya sel beta pankreas (Javeed \& Matveyenko, 2018). Selain itu, stres oksidatif juga akan mengakibatkan kerusakan multiorgan sehingga menjadi pemicu munculnya komplikasi pada pasien DM (Hosseini et al., 2015). Diketahui bahwa ekstrak bunga Etingera elatior memiliki senyawa antioksidan yang sangat tinggi (Wijekoon et al., 2011). Hal ini dapat dilihat bahwa ekstrak bunga dari Etlingera elatior yang diekstrak menggunakan metanol aktivitas antioksidannya lebih tinggi dibandingkan dengan etil asetat. Selisih keduanya sebesar $\left(\mathrm{IC}_{50}=21,14 \mathrm{ug} / \mathrm{ml}\right)$ berbanding dengan $\left(\mathrm{IC}_{50}=68,24 \mathrm{ug} / \mathrm{ml}\right)$ dan melawan secara berurutan radikal bebas 2,2-Diphenyl-1-Picrylhydrazyl (DPPH) (Maimulyati \& Prihandi, 2015). Manfaat lain dari antioksidan yaitu menurunkan pembentukan ROS (reactive oxygen species) di dalam mitokondria. ROS terbentuk karena adanya reaksi antara oksigen dengan elektron bebas yang keluar karena rantaia elektron bocor (Juwita et al., 2018). Hal ini sejalan dengan penelitian Korkina \& Afanasev, yang menyatakan gugus hidroksi pada flavonoid memiliki reaktivitas yang tinggi sebagai donor hydrogen yang akan menstabilkan 
radikan bebas sehingga radikal bebas menjadi senyawa yang lebih stabil (Alfaridz \& Amalia, 2018).

Mekanisme lain dari kerja flavonoid dalam menurunkan kadar gula darah yaitu menghambat fosfodiesterase (PDE) sehingga kadar cAMP (Cyclic Adenosine Monophosphate) dalam sel beta pankreas meningkat. Flavonoid memiliki sifat protektif pada kerusakan sel beta pankreas sebagai penghasil insulin dan dapat meningkatkan sensitivitas insulin (Srey et al., 2014). Hal ini akan merangsang sekresi insulin melalui jalur Ca. Peningkatan cAMP akan menutup kanal $\mathrm{K}^{+}$ATP di dalam membran plasma sel beta. Kemudian terjadi depolarisasi membran dan kanal $\mathrm{Ca}$ akan terbuka agar ion $\mathrm{Ca} 2^{+}$masuk ke dalam sel dan akan terjadi sekresi insulin oleh sel beta pankreas (Kurniawati \& Sianturi, 2016). Zat antioksidan yang dimiliki flavonoid inilah yang berguna dalam menurunkan kadar glukosa darah. Antioksidan juga dapat mengubah apoptosis sel beta pankreas tanpa harus merubah proliferasi sel beta pankreas (Rizky, 2015).

Berbeda pada bagian rimpang, kandungan kimia yang terbanyak yaitu senyawa fenolik. Di mana senyawa fenolik ini juga memiliki peran yang sama dengan flavonoid dalam aktivitas antioksidan. Senyawa fenolik akan memberikan atom hidrogen atau elektron untuk menetralkan radikal bebas sehingga menjadi gugus peroxyl radical (ROOG). Semakin besar kandungan senyawa fenol, semakin besar juga aktivitas antioksidannya (Syarif et al., 2015). Senyawa fitokimia lain yang yang terkandung dalam E.elatior yaitu saponin (Fitrianita et al., 2018). Selain sebagai antimikroba, saponin juga dapat membantu mempercepat proses regenerasi dan repitelisasi karena sifatnya sebagai imunostimulator.
Saponin merupakan bentuk glikosida dari steroid, steroid alkaloid, steroid dengan suatu fungsi nitrogen ataupun triterpinoid. Suatu penelitian mengatakan bahwa saponin steroid akan menimbulkan aktivitas seperti insulin. Di mana pelepasan insulin meningkat dan proses glukogenesis menjadi lebih lambat. Selain itu, saponin steroid dapat menyebabkan aktivitas hipoglikemi (Putra et al., 2016). Secara teori, peningkatan kadar glukosa darah akan menyebabkan kondisi hiperglikemi pada pasien DM akibat adanya hidrolisis pati oleh enzim amilase pankreas dan pengambilan glukosa dari intestinal oleh enzim glukosidase. Penghambatan pada kedua enzim ini akan terjadi perubahan biokimia terhadap hiperglikemia (Nor et al., 2020).

\section{SIMPULAN}

Senyawa kimia yang terdapat di dalam kecombrang (Etlingera elatior) bermanfaat sebagai antihiperglikemi pada pasien Diabetes Mellitus. Di mana E. elatior memiliki senyawa antioksidan pada beberapa senyawa fitokimia seperti flavonoid, fenol, dan saponin yang memiliki kemampuan menghambat enzim amilase dan glukosidase, menetralkan radikal bebas, serta sebagai proteksi terhadap kerusakan sel beta pankreas dalam aktivitas antihiperglikemik pada pasien diabetes melitus sehingga dapat digunakan sebagai bentuk pencegahan atau pengobatan diabetes melitus.

\section{DAFTAR PUSTAKA}

Alfaridz, F., \& Amalia, R. (2018). Review Jurnal : Klasifikasi Dan Aktivitas Farmakologi Dari Senyawa Aktif Flavonoid. Farmaka, 16(3). https://doi.org/10.24198/jf.v16i3.1 7283.g8932 
Andarwulan, N., Batari, R., Sandrasari, D. A., Bolling, B., \& Wijaya, H. (2010). Flavonoid Content and Antioxidant Activity of Vegetables from Indonesia. Food Chemistry, 121(4), 1231-1235.

Chan, E. W. C., Lim, Y. Y., \& Wong, S. K. (2011). Phytochemistry and Pharmacological Properties of Etlingera elatior: A Review. Pharmacognosy Journal, 3(2) : 610.

DOI:10.1016/J.Foodchem.2010.01. 033

Fitrianita, A.,Yardi, \& Musir, A. (2018). Uji Efek Antihiperglikemia Ekstrak Etanol $70 \%$ Daun Kecombrang (Etlingera elatior) pada Tikus Sprague Dawley dengan Penginduksian Aloksan. Jurnal Ilmiah Farmasi, 14(1) : 916.

Ghasemzadeh, A., Jaafar, H. Z. E., Rahmat, A., Ashkani, S. (2015). Secondary Metabolites Constituents and Antioxidant, Anticancer, and Antibacterial Activities of Etlingera elatior (Jack) R.M.Sm Grown in Different Location of Malaysia. BMC Complement Altern Med, 15(1) : 110.

Handayani, S., et al. (2019). Kecombrang (Etlingera elatior) Leaves Ethanol Extract Effect to Lens and Erythrocyte Aldose Reductase Activity In Wistar Strain White Rats (Rattus Norvegicus) Streptozotocin Induced. IOP Conf Ser

Handayani. (2014). Uji Aktivitas Antioksidan Ekstrak Metanol Bunga dan Daun Patikala (Etlingera elatior (Jack) R.M.Sm)
Menggunakan Metode DPPH. Pharm Sci Res, 1(2): 86-93.

Hosseini, A., et al. (2015). Pancreatic Beta Cell Protection or Regeneration with Phytotherapy. Brazilian Journal of Pharmaceutical Sciences, 51(1).

Jackie, T., Haleagrahara, N., \& Chakravarthi, S. (2011). Antioxidant Effects of Etlingera elatior Flower Extract Against Lead Acetate-Induced Perturbations in Free Radical Scavenging Enzymes and Lipid Peroxidation in Rats. BMC Res Notes, 4(1): 67.

Javeed, N., \& Matveyenko, A. V. (2018). Circadian Etiology of Type 2 Diabetes Mellitus. Physiology, 33:138-150.

Juwita, T., Puspitasari, I. M., \& Levita, J. (2018). Torch Ginger (Etlingera elatior): A Review on Its Botanical Aspect, Phytoconstituents and Pharmacology Activities. Pakistan Journal of Biological Sciences, 21(4): 151-165.

Kahn, S. E., Cooper, M. E., \& Del Prato, S. (2014). Pathophysiology and Treatment of Type 2 Diabetes: Perspectives on The Past, Present, and Future. Lancet, 383: 1068 1083.

Kurniawati, E., \& Sianturi, C. Y. (2016). Manfaat Sarang Semut (Myrmecodia pendans) Sebagai Terapi Antidiabetes. Majority, 5(3):38-42.

Li, Q., Kim, Y. R., Vikram, A., Kumar, S., Kassan, M., Gabani, M., Lee, S. K., Jacobs, J. S., Irani, K. (2016). P66Shc-Induced Microrna-34a 
Causes Diabetic Endothelial Dysfunction by Downregulating Sirtuin1. Arterioscler Thromb Vasc Biol, 36: 2394-2403.

Maimulyati, A., Prihadi, A. R. (2015). Cehmical Composition, Phytochemical and Antioxidant Activity from Extract of Etlingera Elantior Flower From Indonesia. Journal of Pharmacognocy and Phytochemistry, 3(6): 233-238.

Nor, N. A. M., Noordin, L., Bakar, N. H. A., Ahmad, W. A. N. W. (2020). Evaluation of Antidiabetic Activities of Etlingera elatior Flower Aqueous Extract In Vitro and In Vivo. Journal of Applied Pharmaceutical Science, 10(08): 043-051.

Patel, C., Satyanand, T., Nirmala, H., Jaya, Y., Sachchidanand, P., Satya, P.S., Pandey, A., Darshan, S. K., Pratap, S. (2013). Antioxidant Activity Of Herbal Plants: A Recent Review. J Drug Discov Ther, 1(8):1-8.

Petersmann, A., Wieland, D. M., Muller, U. A., Landgraf, R., Nauck, M., Freckmann, G., et al... (2019). Definition, Classification and Diagnosis of Diabetes Mellitus. Exp Clin Endocrinol Diabetes, 127(Suppl 1): S1-S7.

Putra, I.W. D. P., Dharmayudha, A. A. G. O., Sudimartini, L. M. (2016). Identifikasi Senyawa Kimia Ekstrak Etanol Daun Kelor(Moringa Oleifera L) Di Bali. Indonesia Medicus Veterinus, 5(5): 464-473.

Rizky, B. (2015). White Dragon Fruit (Hylocereus undatus) Potenial as
Diabetes Melitus Treatment. $J$ Majority, 4(1): 69-72.

Rusanti, A., Sukandar, D., Rudiana, T., \& Adawiah. (2017). Profil Fraksi Sitotoksik terhadap Sel Murine Leukimia P-388 dari Ekstrak Biji Hoje (Etlingera elatior). Jurnal Kimia VALENSI, 3(1) : 79-87.

Silalahi, M. (2016). Etlingera elatior (Jack) R. M. Smith: Manfaat dan Aktivitas Biologi. In: Prosiding Seminar Nasional Pendidikan Biologi dan Biologi. Jurusan Pendidikan Biologi Fakultas Matematika Dan Ilmu Pengetahuan Alam UNY, Yogyakarta. ISBN 9786029516654

Srey, C., C. Sontimuang, S., Thengyai, C., Ovatlarnporn, \& P. Puttarak. (2014). Anti-Glucosidase, AntiAmylase, Anti-Oxidation and Anti-Inflammation Activities of Etlingera elatior Rhizome. J Chem Pharm Res, 6: 885-891.

Syarif, R. A., Sari, F., \& Ahmad, A. R. (2015) Rimpang Kecombrang (Etlingera elatior Jack) Sebagai Sumber Fenolik. Jurnal Fitofarmaka Indonesia, 2(2) : 102106.

WHO. (2019). Classification of Diabetes Mellitus. Geneva: World Health Organization.

Wijekoon, M. M. J. O., Bhat, R., Karim, A. A. (2011). Effect of Extraction Solvents on The Phenolic Compounds and Antioxidant Activities of Bunga Kantan (Etlingera elatior Jack.) Inflorescence. Journal of Food Composition and Analysis, 24 (45), 615-619. 
Willer, A. K., Harreiter, J., \& Pacini, G. (2016). Sex and Gender Differences in Risk, Pathophysiology and Complications of Type 2 Diabetes Mellitus. Endocrine Reviews, 37(3): 278-316.

Zimmet, P., Alberti, K. G., Magliano, D. J., Bennett, P. H. (2016). Diabetes Mellitus Statistics on Prevalence and Mortality: Facts and Fallacies. Nat Rev Endocrinol, 12: 616 622. 
Jurnal Penelitian Perawat Profesional, Volume 3 No 1 Hal 189 - 198, Februari 2021 Global Health Science Group 